\title{
PROBLEMATIKA PENENTUAN HARI RAYA DI INDONESIA PERSPEKTIF FIQH MADHHAB PENGUASA
}

\author{
Moh. Dliya'ul Chaq \\ Institut Agama Islam Bani Fattah Jombang, Indonesia \\ E-mail: yayakrafi@gmail.com
}

\begin{abstract}
Determination holiday in Indonesia always interesting to follow because always ended on absence of power force by government in bringing together the determination method holiday, punctuality holiday as well as the implementation of the holiday. Though fiqh legitimizes power forcefully of the government for not invite sinners, in the corridors maslabah and related issues for the people. Fiqh escorted through governments or that emerges from government in level of history more effectively and show government authority as fiqh dug by khulafâ' al-râshidûn. Then it becomes interesting if the determination holidays in Indonesia viewed from perspective fiqh sect government. Through the model of content analysis interactif and with the document literature found two conclusions that perspective fiqh sect government (1) The Indonesian government has full authority to set the time and method of determining holiday with a model of collective diligence, in the sense chose a method of determining holiday and time holiday with representatives of community organizations. And (2) government decree through collective diligence on holiday must be obeyed and have binding force against Muslims in Indonesia.
\end{abstract}

Keywords: Determination of Holiday, Fiqh Sect Government 


\section{Problematika Penentuan Hari Raya di Indonesia}

Penentuan hari raya di Indonesia selalu menarik untuk diikuti setiap tahunnya, selain karena tidak mampunya pemerintah dalam menyelesaikan masalah yang sama sejak bertahun-tahun yang lalu, juga karena dalam setiap sidang ithbat yang dipimpin oleh menteri agama selalu ada pembiaran atas nama toleransi dan keberagaman terhadap mereka yang tidak mematuhi ketetapan pemerintah tentang hari raya. Jika yang terjadi selalu demikian, maka sidang seperti itu tidak perlu dilakukan sebab selain hasilnya tidak memiliki kekuatan, biaya penyelenggaraan sidang seperti itu tidaklah murah.

Yang menarik lagi adalah banyaknya metode penentuan hari raya di Indonesia yang dimiliki oleh berbagai organisasi massa yang ada di Indonesia. Masing-masing organisasi mempertahankan metode penentuan hilâl. Memang secara fiqh hal ini legitimate. Dua metode yang selalu dipertentangkan sejak fiqh klasik sampai sekarang yaitu ru'yat alhilâl (ru'yat al-bilâl bi al-'ayn) dan ilmu bisâb (ru'yat al-hilâl bi al-ílm). Dua metode ini berdasar pada hadîth Rasulullah saw:

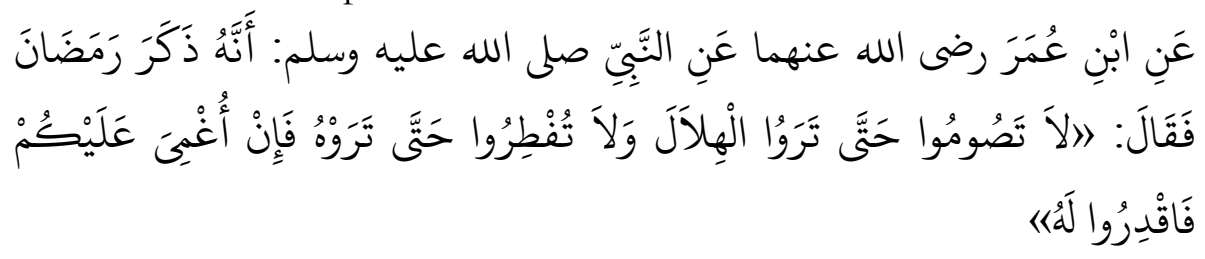

Artinya: "Dari Ibn Umar ra. Dari Rasulullah saw, babwa Rasulullah saw menyebut bulan Ramadlan dan bersabda, "Jangan kalian puasa sampai melihat hilâl (bulan tanggal satu), dan jangan kalian berhari raya sampai melihat hilâl (bulan tanggal satu). Jika awan dilingkupi mendung, maka sempurnakalah (30 hari)." 1

Metode ru'yat al-hilâl telah jelas dinyatakan dalam hadîth itu. Dan menurut Imam al-Nawâwî dalam karyanya Sharh Saḅ̣̂̂ al-Muslim dikatakan kalimat فَاقْدِرُوا لَ memunculkan tiga pemaknaan, yaitu (1) memperkirakan adanya hilâl jika langit cerah dan memperkirakan tidak terlihatnya bilâl jika langit tidak cerah. Ini adalah pendapat Ibn Hanbal yang mengikuti pendapatnya 'Abdullâh Ibn 'Umar, (2) memperkirakan dengan hisâb (ilmu astronomi). Sebagaimana pendapat Ibn Surayj

\footnotetext{
${ }^{1}$ Muslim bin al-Hujjầj, Jâmi' al-Sabîhb li al-Muslim, Vol. III (Beirut: Dar al-Jayl, t.th.), 122., Muhammad bin Ismâ'il al-Bukhârî, Jâmi' al-Sabị̂h li al-Bukhârî, Vol. II (Beirut: Dar Ibn Kathîr, 1987.), 674.
} 
(Shâfi'iyyah), Muțraf bin 'Abdillâh (tâbi'în) dan Ibn Qutaybah (ahli hadîth), dan (3) menyempurnakan 30 hari sebagaimana pendapat Imam al-Ḥanafí, Imam Mâlik, Imam al-Shâfî̀ dan Jumhur ulama' salaf serta khalaf. $^{2}$

Sejaka masa fiqh klasik sampai sekarang di Indonesia, dua metode ini digunakan dan dipertentangkan sehingga di Indonesia menjadi problematika di yang tidak terselesaikan sampai sekarang, terlebih dua organisasi massa terbesar di Indonesia yang terus berbeda. Sebagian fanatik terhadap metode ilmu hisâb, yaitu menentukan hari raya berdasarkan perhitungan edar rembulan, seperti organisasi Muhammadiyah. Sedangkan NU fanatik dengan metode ru'yat al-hilâl melihat hilâl (rembulan) secara langsung saat tanggal 28 di bulan sebelum hari raya. Peluang untuk menyatukan dua ormas terbesar ini sejatinya ada, sebab NU masih mengakui keberadaan ilmu hisâb sebagai penentu kalender. Perbedaan ilmu hisâb versi NU dan Muhammadiyah adalah bahwa Muhammadiyah menjadikan ilmu hisâb sebagai metode utama penentu hari raya dengan kriteria wijûd al-hilâl. Dalam Muktamar Tarjih Muhammadiyah XXVI di Padang Tahun 2003 dapat diambil kesimpulan:

Pertama, Hisâb mempunyai fungsi yang sama dengan ru'yat sebagai pedoman penetapan awal bulan ramadlan, syawal dan dzulhijjah.

Kedua, Hisâb sebagaimana tersebut pada poin satu yang digunakan oleh Majelis Tarjih dan Pengembangan Pemikiran Islam Pimpinan Pusat Muhammadiyah ialah hisâab hakiki dengan kriteria wujûd al-bilâl.

Ketiga, Mutlak yang digunakan adalah mutlak yang didasarkan pada wilâyat al-bukm (Indonesia).

Keempat, Apabila garis batas wujûd al-bilâl pada awal bulan qamariyah tersebut membelah wilayah Indonesia maka kewenangan menetapkan awal bulan tersebut diserahkan kepada kebijakan pimpinan pusat Muhammadiyah. ${ }^{3}$

Sedangkan NU dan mayoritas ormas islam di Indonesia menjadikan ru'yat al-hilâl sebagai metode utama. Dan NU menjadikan ilmu hisâb sebagai metode pendamping dan pembantu ru'yat al-bilâl sehingga muncul istilah imkân al-ru'yah. Dengan kata lain, ilmu hisâb digunakan untuk memperkirakan apakah hilâl mungkin dilihat atau tidak.

\footnotetext{
2 Yậya bin Sharaf al-Nawâwî, Sharh Sahị̂̂ al-Muslim, Vol. VII (Beirut: Dar Ihyâ' alTurâth, t.th.), 186. Lihat juga Muhammad Shams al-Haqq, 'Awn al-Ma'bûd, Vol. VI (Beirut: Dar al-Kutub al-'Ilmiyah, t.th.), 312.

${ }^{3}$ Hasil Muktamar Tarjih Muhammadiyah XXVI di Padang Tahun 2003
} 
Berdasarkan observasinya, kemungkinan bilâl dapat dilihat jika hasil perhitungan ilmu bisâb adalah hilâl berada di atas ufuk tidak kurang dari 2 derajat. Artinya, jika berdasarkan perhitungan ilmu hisab hilal kurang dari 2 derajat, maka hilâl tidak mungkin di rukyah tetapi tetap harus melakukan ru'yat al-hilal sebagai bentuk pelaksanaan terhadap perintah ru'yat dalam nass. Inilah ketetapan NU saat ini.

Jadi jika NU memberikan batas minimal bilal dapat di ru'yat (2 derajat) yang dihitung dengan ilmu hisâb dan menjadikan ru'yat al-bilâl sebagai metode utama, sedangkan Muhammadiyah menjadikan ilmu bisâb sebagai metode yang setara dengan ru'yat al-hilâl dan tidak memberi batas minimal bilâl dapat dilihat. Artinya, selama hasil perhitungannya adalah bilâl tidak nol atau tidak kurang dari nol di atas ufuk maka bilâl dianggap ada atau wujud. Dua cara pandang ini sulit untuk disatukan sehingga sering terjadi perbedaan pelaksanaan hari raya di Indonesia. Belum lagi mereka yang menggunakan perhitungan kalender dengan metode adat aboge.

Sepertinya para pengguna metode hanya memperhatikan content metode dalam fiqh klasik dan ilmu hisâb, tidak memperhatikan peran pemerintah terkait penentuan hari raya. Pengenyampingan peran pemerintah ini akibat dari anggapan sebagaian masyarakat bahwa puasa dan hari raya adalah wilayah privat bukan wilayah publik. Menurut penulis, penentuan puasa dan hari raya adalah urusan publik yang memerlukan peran pemerintah karena; Pertama, penentuan puasa dan hari raya berpengaruh terhadap aktifitas dan tugas di masyarakat di Indonesia; Kedua, penentuan puasa dan hari raya tidak dapat dilakukan oleh masingmasing individu; dan Ketiga, penentuan puasa dan hari raya yang berbeda rentan menimbulkan gesekan sesama umat muslim di wilayah masyarakat umum.

Upaya pelaksanaan hari raya yang serentak telah dilakukan oleh pemerintah tapi dengan cara yang tidak tegas. Dan hasilnya nihil, sampai tahun 2016 pun hari raya tidak serentak. Memang pernah terjadi hari raya yang berlangsung secara serentak di Indonesia, namun itu bukanlah hasil upaya pemerintah, melainkan karena sebuah kebetulan, yaitu kesamaan hasil dari kelompok yang pro ilmu hisâb dengan kelompok yang pro ru'yat al-hilâl serta kelompok yang pro perhitungan berdasarkan adat.

Seharusnya pemerintah menampakkan otoritas untuk menentukan hari raya mengingat masalah ini termasuk masalah publik. Bahkan, fiqh yang diproduksi oleh pemerintah atau penguasa dalam tataran sejarah berlaku sangat efektif. Hal ini dapat dilihat pada fiqh masa khulafâ' al- 
râshidûn yang sangat efektif. ${ }^{4}$ Oleh karenanya, artikel ini membahas problematika penentuan hari raya di indonesia perspektif fiqh mazhab penguasa dengan fokus pembahasan pada (1) apakah pemerintah Indonesia memiliki otoritas penuh dalam menetapkan waktu dan metode penentuan hari raya dan (2) apakah pemerintah Indonesia berhak menghukum pelanggar ketetapan pemerintah tentang hari raya.

\section{Penentuan Hari Raya Dalam Fiqh Peneyempurnaan Tanggal 30 (Ikmâl al-Thalâthîn)}

Di antara cara untuk menetapkan hari raya adalah menyempurnakan bulan Ramadlan 30 hari. Metode ini dilakukan jika bilâl (bulan sabit tanda tanggal satu) belum terlihat, yang didasarkan pada hadîth Rasulullah di atas.

Hadith tersebut tidak secara jelas menyebutkan kalimat 30 hari, tetapi dalam hadîth lain disebutkan. Bahkan hadìth sejenis yang menjelaskan hal ini jumlahnya sangat banyak dan kualitas hadîthnya sabîh li dhâtih atau sahị̂̂h li ghayrih. ${ }^{5}$ Namun demikian, dalam karya al-Nawâwî yang berjudul Shaṛ Sabị̂h al-Muslim terdapat perbedaan pemakanaan kalimat فَاقُدِرُوا لَ

Pertama, bermakna memperkirakan adanya bilâl jika langit cerah dan memperkirakan tidak terlihatnya hilâl jika langit tidak cerah. Ini adalah pendapat Ibn Hanbal yang mengikuti pendapatnya 'Abdullâh Ibn 'Umar.' Dalam fạth al-bârî karya Ibn Hajar al-Asqalânî dan 'awn al-ma'bûd karya Shams al-Haqq terdapat kutipan pendapat Ibn al-Jawzî (Ibn al-Qayyim al-Jawzî) yang menjelaskan bahwa terkait masalah ini terdapat tiga pendapat Ibn Hanbal, yaitu (1) wajib puasa jika tidak terlihat bilâl walaupun tanggal 30 Ramadlan, (2) tidak boleh puasa apapun, (3) dikembalikan kepada keputusan pemerintah atau imam.

Kedua, Bermakna memperkirakan dengan bisâb (ilmu astronomi). Sebagaimana pendapat Ibn Surayj (Shâfi'iyah), Mụtraf bin 'Abdillâh (tâbi'în) dan Ibn Qutaybah (ahli ḥadîth). ${ }^{8}$

\footnotetext{
4 'Abd al-Rahmmân al-Suyụ̂tî, Târîkh al-Khulafâ' (Mesir: Mạtba' al-Sa'âdah, 1952), 67-100.

5 Lihat Bab Puasa dalam Muslim, Jâmi' al-Sabị̣̂ li al-Muslim, Vol. III 122-140; AlBukhârî, Jâmi' al-Sabị̂̂ li al-Bukhârî, Vol. II 674-690; dan al-Nawâwî, Sharh Sabị̣̂ alMuslim, Vol. VII 186.

${ }^{6}$ Muhammad Shams al-Haqq, 'Awn al-Ma'bûd, Vol. VI 312.

${ }^{7}$ Ibn Hajar al-Asqalânî, Fațh al-Bârî, Vol. IV (Beirut: Dâr al-Ma'rifah, t.th.), 122.

${ }^{8}$ Al-Nawâwî, Sharh Sahị̣̂ al-Muslim, Vol. VII 186.
} 
Ketiga, Bermakna menyempurnakan 30 hari sebagaimana pendapat Imam al-Hanafî, Imam Mâlik, Imam al-Shâfi'î dan Jumhur ulama' salaf serta khalaf. ${ }^{9}$ Pendapat ini diperkuat dengan dalil hadîth lain yang secara jelas menyebut kalimat 30 hari.

Jika merujuk pendapat fuqahâ' berbagai mazhab tersebut, penyempurnaan tanggal 30 itu dilakukan jika dalam kondisi langit tertutup mendung sehingga menyulitkan manusia untuk melihat bilâl. ${ }^{10}$ Imam al-Nawâwî menyampaikan bahwa mayoritas ulama menyatakan jika bilâl sulit dilihat karena tertutupi awan maka harus disempurnakan menjadi 30 hari, bukan dengan cara melakukan hisâb ilmu falak (perhitungan kalender dengan ilmu astronomi) karena menurut Imam alNawâwî, jika perintahnya harus melakukan hisâb ketika hilâl tertutup mendung, maka akan menyulitkan bagi umat sebab hanya orang tertentu yang mampu menguasai hisâb ilmu falak. ${ }^{11}$

Teramati bahwa pendapat di atas tentang penyempurnaan 30 hari dalam bulan Ramadlan, memperkirakan hilâl (bulan) dengan ilmu astronomi atau memperkirakan adanya bilâl jika langit cerah adalah upaya untuk menghindari pelaksanaan hukum dalam kondisi keraguan (shakk). Hukum Islam harus dilaksanakan dalam kondisi hati yang mantap dan yakin. Segala hukum yang masih diragukan harus diupayakan menuju kondisi yakin. Menurut kaidah fikih, ketika dalam kondisi ragu maka upaya yang harus dilaksanakan adalah mengembalikan kepada hukum asal. Dalam hal ini, jika bilâl (bulan) tidak terlihat karena mendung, maka dikembalikan kepada hukum asal, yaitu tidak ada bilâl yang muncul sehingga dihukumi tetapnya bulan ramadlan. Hal ini sesuai dengan kaidah fikih:

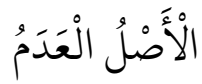

Artinya: "Hukum yang asal adalah tidak ada bukum" 12

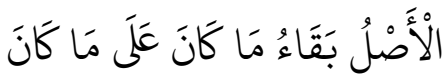

\footnotetext{
${ }^{9}$ Al-Nawâwî, Shaṛ Sabị̂ al-Muslim, Vol. VII 186.

10 Zayn al-Dîn Ibn Nujaym, Al-Baḅr al-Râiq Shaṛ Kanzu al-Daqẩiq, Vol. II (Beirut: Dâr al-Ma'rifah, t.th.), 283; Muḥammad Shams al-Haqq, 'Awn al-Ma'bûd, Vol. VI 312.

11 Al-Nawâwî, Sharh Sabîh al-Muslim, Vol. VII 186.

12 'Abd al-Rahmmân al-Suyụ̂tî, Al-Ashbah wa al-Nadâiir (Beirut: Dâr al-Kutub al-'Ilmîyah, 1981), 57; Ibn Nujaym, al-Ashbah wa al-Nadâ’ir (Beirut: Dâr al-Kutub al-'Ilmîyah, 1980), 63.
} 
Artinya: "Hukum yang asal adalah tetapnya perkara yang sebelumnya telah tetap" 13

Dengan demikian, metode penetapan Idul Fitri dengan menyempurnakan tanggal 30 Ramadlan ketika bilâl tidak terlihat pada tanggal 29 (terbenamnya matahari tanggal 28) adalah upaya yang paling tepat untuk menghilangkan keraguan.

\section{Ru'yat al-Hilâl (Melihat Hilâl)}

Menurut Abu al-Barakât Husayn bin 'Ammâr (Hanafìyah) bahwa hukum ru'yat al-bilâl bi al-'ayni adalah fardu kifâyah. ${ }^{14}$ Dalam hal penerimaan hasil ri'yat al-hilâl, fuqahâ' berbagai mazhab berbeda pendapat:

a. Menurut Fuqahâ' Hanafîyah

Menurut Wahbah Zuhaylî bahwa fuqahâ' Hanafîyah menyatakan penentuan awal ramadlan dan hari raya harus dengan melihat hilâl menggunakan mata kepala (ru'yat al-bilâl bi al-'ayn). Oleh karenanya, penentuan dengan hisâb atau ilmu falak (ru'yat al-bilâl bi al-ílm) tidak diperbolehkan. ${ }^{15}$ Dan ri'yat al-hilâl dapat diterima dan dijadikan pedoman untuk memutuskan hari raya jika:

Pertama, dipersaksikan di depan hakim oleh minimal dua laki-laki atau satu lak-laki dan dua perempuan yang adil dalam keadaan langit tertutup sesuatu yang menghalangi pandangan melihat bilâl seperti mendung, awan, debu, dan lain sebagainya. ${ }^{16}$ Menurut Abû Bakar alHaddâdî al-'Ibâdî persaksian dalam keadaan langit tertutup mendung atau sejenisnya diterima karena sangat mungkin satu orang melihat bilâl dalam keadaan seperti ini walaupun yang lainnya tidak melihat. ${ }^{17}$

Kedua, dipersaksikan di depan hakim oleh orang banyak dalam keadaan langit cerah dan tidak tertutup sesuatu yang menghalangi pandangan melihat hilâl seperti mendung, awan, debu, dan lain

\footnotetext{
${ }^{13}$ Ibn Nujaym, al-Ashbah, 57; al-Suyụ̂tî, Al-Ashbah, 51; Tâj al-Dîn al-Subkî, al-Ashbah wa al-Nadâir (Beirut: Dâr al-Kutub al-'Ilmîyah, 1991), 23.

14 'Abû al-Barakât Husayn bin 'Ammâr, Marâqî al-Fallâh, Vol. I (t.tp.: Maktabah Shamelah, t.th.), 244.

15 Wahbah Zuhaylî, Al-Fiqh al-Islâmiy wa Adillatuh, Vol. III (Beirut: Dar al-Fikr, 2000), 33.

16 Ibn Mawdûd al-Mụsilî, Al-Ikhtiyâr li Ta'lîl al-Mukhtâr, Vol. I (t.tp.: Maktabah Shamelah, t.th.), 10; Abû Bakr al-Haddâdî al-'Ibâdî, Al-Jawharah al-Munîrah, Vol. II (t.tp.: Maktabah Shamelah, t.th.), 21.

${ }^{17}$ Al-'Ibâdî, Al-Jawharah, 22.
} 
sebagainya. Jika langit cerah dan dipersaksikan sedikit orang, maka persaksiannya tidak bisa diterima oleh hakim karena sangat mungkin bahwa apa yang dilihatnya adalah salah mengingat mayoritas orang tidak melihatnya. ${ }^{18}$

Perdebatan ulama' hanafiyah terkait persaksian dan penerimaan ru'yat al-hilâl ramadlan dan syawal adalah tentang kualitas dan kuantitas pelaku ru'yat al-hilâl. Terkait kuantitas pelaku ru'yat al-bilâl, ulama' mayoritas hanafiyah membatasi minimal dengan dua orang laki-laki atau satu laki-laki dengan dua wanita jika kondisi langit tidak cerah dan harus orang banyak jika kondisi langit cerah. Namun Abû Bakar al-Haddâdî al-'Tbâdî menyatakan sebenarnya tidak ada batasan walupun banyak yang merujuk pendapat Abû Yûsuf yang menyatakan batasan minimalnya dianggap banyak (jika kondisi langit cerah) adalah 50 orang. Namun menurut al-Haddâdî al-'Ibâdî bahwa pendapat yang benar adalah dikembalikan kepada imam (pemerintah) berapapun jumlah pelaku ri'yat al-bilâl. ${ }^{19}$

Terkait kualitas pelaku ru'yat al-bilâl, mayoritas hanafiyah menyatakan bahwa pelaku ru'yat al-hilâl dapat diterima hasil ru'yatnya jika tergolong 'adâlah. ${ }^{20}$ Di antara yang berpendapat demikian adalah Abû Hanîfah, ${ }^{21}$ al-Hasan, ${ }^{22}$ al-Sarakhsî, ${ }^{23}$ Ibn Nujaym, ${ }^{24}$ Ibn Mawdûd al-Mụsilîi, ${ }^{25}$ dan al-Haddâdî al-'Ibâdî. ${ }^{26}$ Adanya persyaratan ini menurut Ibn Nujaym dan al-Sarakhsî karena bilâl hari raya berdampak pada banyak orang yang pberhenti puasa ramadlan sehingga sama halnya dengan masalah yang berhubungan dengan hak orang banyak. ${ }^{27}$ Oleh karenanya orang yang diterima persaksiannya ketika melihat bilal

\footnotetext{
18 Al-Mụsilî, Al-Ikhtiyâr li Ta'lîl al-Mukhtâr, Vol. I 10; Al-'Ibâdî, Al-Jawharah al-Munîrah, Vol. II 22.

19 Al-'Tbâdî, Al-Jawharah, 22

20 'Adâlah yaitu meninggalkan dosa besar, meninggalkan dosa kecil secara terus menerus dan meninggalkan sesuatu yang menghilangkan kewibawaan (murû'ab). Lihat Ibn Nujaym, Al-Bậr al-Râiq Sharh Kanzu al-Daqẩiq, Vol. II (Beirut: Dâr al-Ma'rifah, t.th.), 286.

${ }^{21}$ Shams al-Dîn al-Sarakhsî, Al-Mabsụt li al-Sarakhsî, Vol. III (Beirut: Dâr al-Fikr, 2000), 252.

22 Al-Sarakhsî, Al-Mabsụt, 252.

23 Al-Sarakhsî, Al-Mabsụt, 252.

24 Ibn Nujaym, al-Babr al-Râiq, 286 dan 187.

${ }^{25}$ Al-Mûsilî, Al-Ikbtiyâr li Ta'lîl al-Mukbtâr, Vol. I, 10.

26 Al-'Ibâdî, Al-Jawharah al-Munîrah, Vol. II 21.

27 Ibn Nujaym, Al-Babr al-Râiq Shaṛ Kanæu al-Daqâiq, Vol. II 287; Al-Sarakhsî, AlMabsụt li al-Sarakhsî, Vol. III 252.
} 
ramadlan atau hari raya harus jelas-jelas memiliki sifat 'adâlah. Dan menurut pendapat Abû Hanîfah yang dinukil Ibn Nujaym bahwa orang yang tidak jelas 'adâlah-nya (mastûr al-hâl) maka persaksiannya diterima. ${ }^{28}$ Jika orang yang melihat hilâl dan mempersaksikan keterangannya tidak 'adâlah atau sudah taubat dari perbuatan yang mencederai 'adâlahnya maka persaksiannya tetap tidak dapat diterima sebagaimana pendapat Abû Hanîfah dan al-Hasan. ${ }^{29}$ Sementara alSarakhsî menyatakan bahwa orang yang taubat dari sifat yang mencederai 'adâlabnya maka persaksiannya dapat diterima sebagaimana sahabat Rasul menerima persaksian Abû Bakrah yang sempat menuduh zina orang lain dan ia telah bertaubat. ${ }^{30}$ Sementara ulama' hanafîyah yang tidak mensyaratkan 'adâlah dalam persaksian hilâl idul fitri di antaranya adalah al-Ṭahâwi. ${ }^{31}$

Perdebatan ulama' hanafiyah terkait persaksian dan penerimaan ru'yat al-hilâl ramadlan dan syawal adalah tentang sikap pelaku ru'yat albilâl bagi dirinya sendiri. Mayoritas hanafîyah di antaranya diungkap oleh Ibn Mawdûd al-Mụsilî, Abû Bakar al-Haddâdî al-'Ibâdî dan Ibn Nujaym bahwa orang yang melihat bilâl ramadlan, wajib baginya melakukan apa yang dilihatnya walaupun persaksiannya ditolak oleh hakim. Jika ia tidak puasa karena melihat hilâl, maka wajib baginya qadâ. ${ }^{32}$ Bahkan menurut Abû Bakar al-Haddâdî al-'Ibâdî hal ini menunjukkan bahwa penentuan awal puasa tidak disyaratkan untuk dipersaksikan di depan hakim karena hal ini adalah urusan agama yang cukup dengan berita dari orang yang memiliki sifat 'adâlah maka orang yang mendengarkannya boleh untuk mengikutinya. ${ }^{33}$ Jika bilâl yang dilihat adalah hilal syawal maka wajib mengikuti imam atau pemimpin. Jika orang yang melihat bilâl syawal persaksiannya ditolak hakim namun ia tetap membatalkan puasa karena berpedoman pada apa yang dilihatnya, maka wajib baginya qadâ. ${ }^{34}$ Sedangkan menurut alḤasan, Ibn Sîrîn dan Imam 'Ạtâ' menyatakan bahwa orang yang melihat bilâl ramdlan atau syawal tetap wajib mengikuti Imam atau

\footnotetext{
28 Zayn al-Dîn Ibn Nujaym, Al-Bạ̣r al-Râiq Shaṛ Kanqu al-Daqẩiq, Vol. II 287.

29 Al-Sarakhsî, Al-Mabsụt, 254.

${ }^{30}$ Al-Sarakhsî, Al-Mabsụt, 254

${ }^{31}$ Al-Sarakhsî, Al-Mabsụt, 252:

32 Al-Mụsilî, Al-Ikbtiyâr li Ta'lîl al-Mukbtâr, Vol. I 10; Al-'Ibâdî, Al-Jawharah al-Munîrah Vol. II 20.

33 Al-'Ibâdî, Al-Jawharah, 21.

${ }^{34}$ Al-Mụsilî, al-Ikhtiyâr, 10.
} 
pemerintah apapun keadaannya. ${ }^{35}$ Ibn Nujaym al-Hanafî menyatakan bahwa dasar dari ketentuan harus berpuasa bagi orang yang melihat bilâl ramadlan walaupun persaksiannya ditolak hakim adalah QS. alBaqarah: 185;

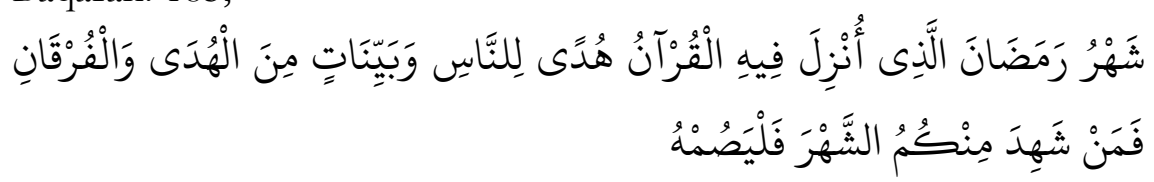

Artinya: "Beberapa hari yang ditentukan itu ialah) bulan Ramadhan, bulan yang di dalamnya diturunkan (permulaan) Al Quran sebagai petunjuk bagi manusia dan penjelasan-penjelasan mengenai petunjuk. itu dan pembeda (antara yang bak dan yang bathil). karena itu, Barangsiapa di antara kamu menyaksikan (di negeri tempat tinggalnya) di bulan itu, Maka hendaklah ia berpuasa pada bulan itu".

Sedangkan dasar untuk kewajiban tetap berpuasa (mengikuti putusan hakim yang menolaknya) bagi orang yang melihat hilal hari raya adalah hadith Rasulullah, ${ }^{36}$ sebagai berikut:

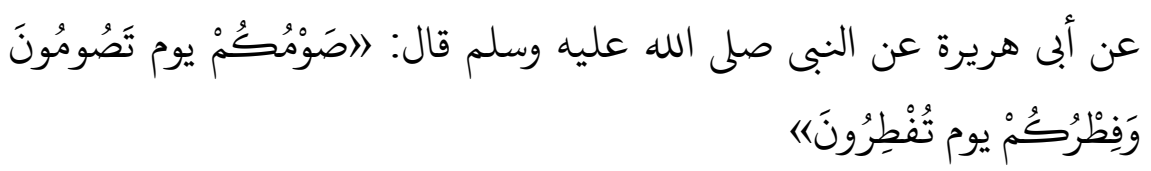

Artinya: "Dari Abu Hurayrah bahwa Nabi bersabda: Puasa kalian adalah di mana kalian semua berpuasa, dan hari raya kalian adalah di mana kalian semua berhari raya" 37

Menurut Ibn Nujaym, melaksanakan sesuatu yang berbeda dengan apa yang dilakukan oleh banyak orang dalam hal penentuan hari raya adalah petunjuk bahwa apa yang dilihatnya adalah salah. ${ }^{38}$ Ibn Nujaym juga menyatakan bahwa 'illat kewajiban mengikuti imam walaupun orang tersebut melihat hilâl hari raya adalah ikhtiyạt (hati-hati dalam memutuskan hukum). ${ }^{39}$ Dan menurut Ibn Mawdûd al-Mụsilî bahwa konsekwensi ketika awal puasa atau hari raya sudah ditetapkan

\footnotetext{
35 Ibn Nujaym, Al-Bạbr al-Râiq Shaṛh Kanzu al-Daqẩiq, Vol. II 286.

36 Ibn Nujaym, Al-Babr, 286.

37 'Alî bin 'Umar al-Dâruqụtnî, Sunan al-Dâruqụtnî, Vol. II (Beirut: Dâr al-Ma'rifah, 1966), 164.

38 Ibn Nujaym, Al-Bạ̣r al-Râiq Sharh Kanzu al-Daqâ’iq, Vol. II (Beirut: Dâr al-Ma'rifah, t.th.), 286.

${ }^{39}$ Ibn Nujaym, Al-Bạh, 286.
} 
pemerintah melalui persaksian, maka wajib bagi seluruh penduduk Negara untuk mengikutinya. ${ }^{40}$

Dengan demikian, dapat disimpulkan bahwa fuqahâ' hanafîyah lebih memilih ketetapan pemerintah dalam menentukan hari raya. Adapun pemerintah dalam menetapkannya harus mendasarkan pada persaksian orang-orang yang melakukan ru'yat al-bilâl bi al-'ayn, bukan pada ru'yat al-bilâl bi al-ílm (ilmu bisiâb).

b. Menurut Fuqahâ' Mâlikîyah

Menurut Wahbah Zuhaylî bahwa fuqahâ' Mâlikîyah menyatakan penentuan awal ramadlan dan hari raya harus dengan melihat hilâl menggunakan mata kepala (ru'yat al-bilâl bi al-'ayn) tidak boleh berpedoman pada hasil ilmu bisấb atau ilmu falak (ru'yat al-bilâl bi al'ilm) baik untuk diri sendiri atau orang lain. ${ }^{41}$ Menurut fuqahâ' Mâlikîyah bahwa ru'yat al-bilâl dapat diterima dan dijadikan pedoman untuk memutuskan hari raya jika:

Pertama, dipersaksikan di depan hakim. Artinya setiap orang yang melihat hilal wajib mendatangi hakim dan mempersaksikan apa yang dilihatnya. ${ }^{42}$

Kedua, dipersaksikan di depan hakim oleh minimal dua orang yang memiliki sifat 'adâlah dalam kondisi langit mendung. Sebagaimana dikatakan oleh Imâm Mâlik, Yûsuf bin 'Abdillâh al-Namrî alQurtubî, ${ }^{43}$ Aḥmad bin Muhammad al-Sâwî, ${ }^{44}$ dan Muhammad bin Yûsuf al-'Abdari. ${ }^{45}$

Ketiga, dipersaksikan di depan hakim oleh orang banyak dalam kondisi langit mendung atau cerah. Mengingat meratanya orang melihat hilâl, maka tidak disyaratkan saksi atau pelaku ru'yat hilâl adalah orang yang memiliki sifat 'adâlah. Sebagaimana dikatakan oleh Yûsuf bin 'Abdillâh al-Namrî al-Qurtubî,, al-Kharshî, ${ }^{47}$ Abu al-

\footnotetext{
40 Al-Mụsilî, al-Ikhtiyâr li Ta'lîl al-Mukhtâr, Vol. I 10.

${ }^{41}$ Wahbah Zuhaylî, Al-Fiqh al-Islâmiy wa Adillatubu, Vol. III (Beirut: Dar al-Fikr, 2000), 24.

42 Aḥmad bin Muhammad al-Ṣ̂wî, Hâshiyah al-Sâwî 'Ala Sharh al-Saghîr, Vol. III (t.tp.: Maktabah Shamelah, t.th.), 236; Abû al-Barakât al-Dardîr, Al-Sharh al-Kabîr li al-Dardîr, Vol. I (t.tp.: Maktabah Shamelah, t.th.), 511.

43 Yûsûf bin 'Abdillâh al-Namrî al-Qurtubî, Al-Kâfî fi al-Fiqh Abli al-Madînah al-Mâlikî̀, Vol. I (Riyad: Maktabah a-lRiyâd al-Hadîthah, 1980), 334.

${ }^{44}$ Al-Sâwî, Hâshiyah al-Sânî' 'Ala Sharh al-Saghîr, Vol. III 235.

${ }^{45}$ Muḥammad bin Yûsûf al-'Abdarî, Al-Tâj Wa Iklîl Li Mukbtasar Khalîl, Vol. II (Beirut: Dâr al-Fikr, t.th.), 381.

46 Al-Quṛtubî, Al-Kâfî fi al-Fiqh Abli al-Madînah al-Mâlikî̀, Vol. I 334.
} 
Barakât al-Dardîr, ${ }^{48}$ dan Aḥmad bin Muhammad al-Ṣ̂wî. ${ }^{49}$ Yang dimaksud orang banyak menurut mâlikîyah adalah saksi yang mencapai bilangan yang tidak mungkin sepakat untuk berbohong. ${ }^{50}$

Pendapat mâlikîyah ini menunjukkan bahwa 'adâlah atau kualitas pelaku ru'yat al-hilâl menjadi syarat diterimanya persaksian ru'yat al-hilâl ketika hanya disaksikan oleh dua orang. Oleh karenanya, persaksian wanita, para budak atau satu laki-laki yang adil tidak dapat diterima. Pendapat ini menurut al-'Abdarî adalah pendapat Imam Mâlik yang diikuti oleh ulama' mâlikîyah. ${ }^{51}$

Perdebatan fuqahâ' mâlikîyah adalah tentang kondisi langit cerah tetapi hilâl hanya disaksikan oleh dua orang saja. Menurut sebagian mâlikiyah jika keadaan langit cerah dan hanya persaksian dua orang maka persaksiannnya dapat diterima selama hanya meliputi wilayah kota kecil, jika kota besar maka tidak diterima kecuali dalam keadaan mendung. Ini adalah pendapat Ibn 'Arafah, ${ }^{52}$ dan al-Lukhamî. ${ }^{53}$ Adapun pendapat yang mashur dalam ulama' mâlikîyah adalah diterimanya persaksian dua orang ini baik mendung atau cerah, baik dalam wilayah kota besar atau kecil, sebagaimana diungkapkan oleh Imam Mâlik, Muhammad bin Yûsuf al-Abdarî, ${ }^{54}$ Yûsuf bin 'Abdillâh al-Namrî al-Qurtubî. ${ }^{55}$

Menurut fuqahâ' mâlikîyah, hilâl syawal yang hanya dilihat oleh satu orang, persaksiannya ditolak dan orang itu harus mengikuti keputusan hakim sehingga tidak boleh berhari raya. Ini adalah pendapat Imam Mâlik yang diikuti Ibn al-Qâsim, Muḥammad bin Yûsuf al-Abdarî, ${ }^{56}$ dan Yûsuf bin 'Abdillâh al-Namrî al-Qựtubî. ${ }^{57}$ Namun orang itu

\footnotetext{
${ }^{47}$ Muhạmmad al-Kharshî, Sharh Mukhtasar Khalîl, Vol. II (Beirut: Dâr al-Fikr, t.th.), 235. 48 'Abû al-Barakât al-Dardîr, Al-Sharh al-Kabîr li al-Dardîr, Vol. I (t.tp.: Maktabah Shamelah, t.th.), 510 .

49 Al-Sâwî, Hâshiyah al-Sâwî 'ala Sharh al-Saghîr, Vol. III 235; Wahbah Zuhaylî, Al-Fiqh, Vol. III 34.

${ }^{50}$ Muhammad 'Arafah al-Dasûqî, Hâshiyah al-Dasûqî 'alâ al-Sharh al-Kabîr, Vol. I (Beirut: Dâr al-Fikr, t.th.), 510; Al-Ṣ̂wî, Hâashiyah, 235.

51 Al-'Abdarî, Al-Tâj wa Iklîl li Mukhtạsar Khalîl, Vol. II 381; Wahbah, Al-Fiqh, Vol. III 34.

52 Al-'Abdarî, al-Tâj, Vol. II 382.

53 Al-'Abdarî, al-Tâj; Vol. II 382.

54 Al-'Abdarî, al-Tâj; Vol. II 382.

55 Al-Qurtubî, al-Kâfî, Vol. I 334.

56 Al-'Abdarî, al-Tâj; Vol. II 389.

${ }^{57}$ Al-Qurtubî, al-Istidhkâr, Vol. III (Beirut: Dâr al-Kutub al-'Ilmîyah, 2000), 280.
} 
wajib niat hari raya tetapi tidak boleh makan sebagaimana pendapat Imam Ashhâb, ${ }^{58}$ dan al-Kharshî. ${ }^{59}$ Bahkan Abû al-Barakât al-Dardîr menyatakan, jika orang itu tetap berhari raya dan memperlihatkan hari rayanya secara jelas pada masyarakat, maka pemerintah boleh menghukum $\left(t a^{\prime} \gamma^{\prime} r\right){ }^{60}$

Menurut Yûsuf bin 'Abdillah al-Namrî al-Qurtubî, konsekwensi jika persaksiannya hanya dilakukan oleh hakim daerah, maka keputusan hanya berlaku bagi daerah setempat. Namun jika ditetapkan oleh pemerintah pusat maka berlaku untuk seluruh warga di seluruh Negara tersebut. ${ }^{61}$

c. Menurut Fuqahâ' Shâfi'îyah

Terkait hasil ru'yat al-bilâl, dalam mazhab shâfi'îyah terlihat ada perbedaan tentang kualitas dan kuantitas serta lingkup keberlakuan hasil ru'yat al-bilâl. Jika bilâl dilihat oleh satu orang yang tidak dipersaksikan, baik tergolong memiliki sifat 'adâlah atau tidak maka hasil ru'yat seperti ini tidak berlaku umum satu negara, tetapi berlaku untuk:

Pertama, diri si pelihat hilâl. Sebagian ulama mensyaratkan tidak boleh memperlihatkan pada khalayak tentang hari raya yang dilakukannya (sirr). Sebagaimana pendapat Imam al-Shâfîî, ${ }^{62}$ alMâwardî, ${ }^{63}$ Ibrâhim bin 'Alî al-Shîrâzî. ${ }^{64}$

Kedua, orang-orang yang meyakini kebenaran pelihat bilâl sebagaimana pendapat Zayn al-Dîn al-Malîbârî. ${ }^{65}$

Sedangkan ru'yat al-hilal yang dapat diterima dan dijadikan pedoman untuk memutuskan hari raya secara umum untuk masyarakat luas, menurut shâfi'îyah jika dipersaksikan di depan hakim oleh minimal satu orang yang memiliki sifat 'adâlah, sebagaimana yang diungkap oleh 'Abd al-Raḥmân al-Jâzirî dan Wahbah Zuhayli. Tetapi pendapat lain mengatakan minimal dipersaksikan dua orang

\footnotetext{
58 Al-'Abdarî, Al-Tâj, Vol. II 389:

59 Al-Kharshî, Sharh Mubtasar Khalîl, Vol. II 237.

${ }^{60}$ Al-Dardîr, Al-Sharh al-Kabîr li al-Dardîr, Vol. I 512.

${ }^{61}$ Al-Qurtubî, Al-Kâfî, Vol. I 335.

62 Muhammad bin Idrîs al-Shâfi'̂̂, Al-'Umm, Vol. II (Beirut: Dâr al-Ma'rifah, t.th.), 95.

${ }^{63} \mathrm{Al}$-Mâwardî, Al-Iqnâ' li al-Mâwardî, Vol. I (t.tp.: Maktabah Shamelah, t.th.), 91; AlMâwardî, al-Iqnâ' li al-Mâwardî, Vol. I (t.tp.: Maktabah Shamelah, t.th.), 73.

${ }^{64}$ Ibrâhîm bin 'Alî al-Shîrâzî, Al-Tanbîh (Beirut: 'Alam al-Kutub, t.th.), 65.

${ }^{65}$ Zayn al-Dîn al-Malîbârî, Faț al-Mu'în (Beirut: Dâr al-Fikr, t.th.), 217.

${ }^{66}$ Wahbah, al-Fiqh al-Islâmiy, Vol. III 35; 'Al-Jazirî, Al-Fiqh 'alâ Madhâbib al-Arba'ah, Vol. I (t.tp.: Maktabah Shamelah, t.th.), 879.
} 
yang 'adâlah sebagaimana pendapat Imam al-Shâfî̀, al-Mâwardî, ${ }^{67}$ dan Ibrâhîm bin 'Alî al-Shîrâzî. ${ }^{68}$ Namun demikian, Imam al-Mâwardî menyatakan bahwa jika bilâl hanya dilihat oleh masyarakat luas di daerah tertentu dalam keadaan mendung, sementara daerah lain tidak terlihat karena mendung, maka persaksian bilâl itu hanya berlaku pada daerah yang melihat saja, tidak pada daerah lain yang mendung dan tidak terlihat. ${ }^{69}$

Dengan demikian, dapat dikatakan bahwa hasil ru'yat al-bilâl yang dapat dijadikan pedoman masyarakat luas menurut mazhab ini adalah hasil ru'yat al-hilâl yang dipersaksikan di depan hakim.

d. Menurut Fuqahâ' Hanâbilah

Hanâbilah menyatakan bahwa hari raya hanya dapat diberlakukan jika dipersaksikan oleh dua orang yang adil dan boleh perempuan. Bahkan jika ada yang melihat hilal hari raya seorang diri, maka orang itu pun tidak boleh berhari raya sendirian. Atau bahkan jika ada dua orang yang melihat bilâl tetapi tidak dipersaksikan di depan hakim, maka hasil pengelihatannya itu tidak dapat dipakai untuk dirinya sendiri atau orang lain. Hal ini didasarkan pada hadîth bahwa perintah berhari raya menggunakan bentuk jamak, berarti harus dilaksanakan oleh orang banyak. ${ }^{70}$

Dari uraian fiqh empat mazhab tentang ru'yat al-bilâl, bahwa semua mazhab sepakat dalam penentuan hari raya terdapat campur tangan pemerintah. Pemerintah melalui hakim memiliki hak untuk menerima dan menolak persaksian orang yang melihat hilâl. Ulama' empat mazhab hanya berbeda mengenai bilangan minimum orang yang bersaksi dalam melihat bilâl.

\section{Ilmu Ḥisâb (Ru'yat al-Hilâl bi al-‘Ilmi)}

Metode penentuan hari raya yang ketiga adalah dengan ilmu bisâb yang bisa juga di sebut dengan ri'yat al-bilâl bi al-'ilm.

Dalam karya al-Nawâwî yang berjudul Shaṛ̣ Saḥịh al-Muslim dikatakan terdapat perbedaan pemakanaan kalimat فَاقْدِرُوالَ Salah satunya adalah kelompok ulama' yang memberi maksud dengan memperkirakan

\footnotetext{
${ }^{67}$ Al-Mâwardî, al-Hâẩ al-Kabîr, Vol. III 887; Al-Mâwardî, Al-Iqnâ’ li al-Mâwardî, Vol. I 73.

68 Al-Shîrâzî, Al-Tanbîh, 65.

${ }^{69} \mathrm{Al}$-Mâwardî, al-Iqnâ' li al-Mâwwardî, Vol. I 73.

${ }^{70}$ Wahbah, al-Fiqh al-Islâmiy Wa Adillatubu, Vol. III 36; Al-Jazirî, al-Fiqh 'alâ Madhâhib alArba'ab, Vol. I 879.
} 
dengan hisâb (ilmu astronomi), sebagaimana pendapat Ibn Surayj (Shâfi'iyah), Mụtraf bin Abdillah (tâbi'în) dan Ibn Qutaybah (ahli ḩadîth). ${ }^{71}$ Menurut al-Subkî, ilmu hisâb dapat dijadikan dasar penetapan hari raya atau puasa, bahkan jika terjadi persaksian yang menyalahi ilmu hisâb, artinya jika hasil ilmu hisâb menyatakan bahwa bilâl tidak mungkin dilihat (imkân al-ru'yab) namun terdapat saksi yang menyatakan bilâl telah terlihat, maka persaksiannya ditolak. ${ }^{72}$

Kritik terhadap metode ini sangat banyak sekali. Dimulai dari ulama' ḩanafiyah yang jelas melarang ilmu hisab adalah Alâ' al-Dîn al-Haskafi, ${ }^{73}$ Shams al-Aimmah al-Khalwânî, ${ }^{74}$ dan Ibn 'Âbidîn. ${ }^{75}$ Menurut Ibn 'Âbidîn ulama' hanafiyah sepakat melarang berpedoman pada ilmu hisâb dan melarang untuk mengamalkan hasil hisâb bahkan jika mereka adil dan dalam jumlah banyak. Termasuk juga larangan menggunakan hasil bisâb untuk dirinya sendiri. ${ }^{76}$ Ibn 'Âbidîn mengkritik pendapat al-Subkî (shâfi'îyah) yang menyatakan bahwa hasil hisâb itu sifatnya pasti, sedangkan persaksian melihat bilâl itu masih tidak pasti (dann) sehingga hisâb tanpa kemungkinan hilâl bisa dilihat (imkân al-ru'yah) pun dapat diamalkan. ${ }^{77}$ Menurut Ibn 'Âbidîn pendapat al-Subkî telah dikritik sendiri oleh Ibn Hajar al-Haytâmî dan Imam al-Ramlî (shâfî̀yah) dengan menyatakan bahwa Allah dalam nạss shara' tidak mengilangkan (meniadakan) hal itu. Selain itu, bahwa kita adalah orang awam sehingga

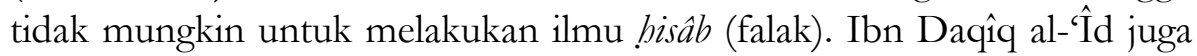
berpendapat bahwa ilmu ḩisâb tidak dapat dijadikan dasar bahkan untuk shalat. Pendapat-pendapat ini diamini oleh Ibn 'Âbidîn. ${ }^{78}$

Sebagian kecil ulama' hanafiyah memang menyatakan bahwa ilmu bisâb dapat dijadikan pedoman penentuan awal puasa dan hari raya sebagaimana sempat diungkapkan oleh 'Alâ' al-Dîn al-Haskafî (Hanafiyah) walaupun beliau tidak sepakat dengan pendapat ini. ${ }^{79}$ Namun Ibn 'Âbidîn menyatakan bahwa apa yang disampaikan 'Alâ' al-Dîn alHaskafî masih perlu diperjelas sebab memiliki kemungkinan maksud,

\footnotetext{
${ }^{71}$ Al-Nawâwî, Sharh Sậ̣̣̂ al-Muslim, Vol. VII (Beirut: Dar Ihyâ' al-Turâth, t.th.), 186.

${ }^{72}$ Abû Bakr al-Dimyậtî, Hâshiyah I'anat al-Tâlibîn, Vol. II (Beirut: Dâr al-Fikr, t.th.), 216.

73 'Alâ' al-Dîn al-Haskafî, Durr al-Mukhtâr, Vol. II (Beirut: Dâr al-Fikr, 2000), 387.

${ }^{74}$ Ibn 'Âbidîn, Hâshiyah Radd al-Mukehtâr, Vol. II (Beirut: Dâr al-Fikr, 2000), 387.

${ }^{75}$ Ibn 'Âbidîn, Hâshiyah, 387

${ }^{76}$ Ibn 'Âbidîn, Hâshiyah, 387

${ }^{77}$ Ibn 'Âbidîn, Hâshiyah, 387

${ }^{78}$ Ibn 'Âbidîn, Hâshiyah, 387

${ }^{79}$ Al-Haskafî, Durr al-Mukbtâr, Vol. II 387.
} 
yaitu boleh untuk mempelajarinya tetapi tidak boleh dijadikan sandaran sebagaimana pendapat Qậî Abd al-Jabbâr (Hanafîyah) atau mungkin boleh untuk dijadikan pedoman selama banyak pendapat ahli hisâb yang sama sebagaimana pendapat Ibn Muqâil (Hanafîyah). ${ }^{80}$

Adapun ulama' mâlikîyah yang melarang ilmu hisab adalah Imam Mâlik, Ibn Nâfi', Ibn al-'Arabî, ${ }^{81}$ Ibn al-Hâjib, ${ }^{82}$ Shams al-Dîn alTarablisî, ${ }^{83}$ Muhammad 'Arafah al-Dasûqî, ${ }^{84}$ Shihâb al-Dîn al-Qarafî, ${ }^{85}$ Aḥmad bin Muhammad al-Ṣâwî, ${ }^{86}$ Muhammad al-Kharshî, ${ }^{87}$ Ibn Yûnus, Muhammad bin Yûsûf al-'Abdarî. ${ }^{88}$ Bahkan menurut Imam Mâlik yang juga disampaikan oleh Ibn Nâfi' bahwa Imam atau pemimpin yang menetapkan puasa atau hari raya berdasarkan ilmu hisâb tidak boleh diikuti. ${ }^{89}$ Al-Dasûqî beralasan bahwa penentuan hilâl dengan ilmu hisâb bukanlah metode shar'îyah, ${ }^{90}$ karena metode shara' dalam hal ini, menurut al-Kharshî hanya dengan ru'yat al-hilâl, persaksian dan menyempurnakan bilangan 30 dalam sebulan. ${ }^{91}$ Menurut Muhammad bin Yûsûf al-'Abdarî jika shara' sudah menetapkan metode-metode tersebut maka tidak boleh ada tambahan metode seperti hisâb. ${ }^{92}$

Menurut al-Ṭarablisî bahwa penentuan ramadlan dan syawal dengan hisâb memang sering digunakan oleh ulama' Baghdad. Mereka berdasar pada pendapatnya Ibn Shurayj (Shâfi'îyah). Mereka juga menyatakan bahwa apa yang dilakukan juga didasarkan dari pendapat Imam Mâlik. Hal ini adalah riwayat yang shâdh (sangat langka). ${ }^{93}$ Ibn 'Arafah (Muhammad 'Arafat al-Dasûqî) menyatakan bahwa saya tidak pernah tahu ulama' mâlikî berpedoman pada ahli astronomi dalam hal ini,

${ }^{80}$ Ibn ‘Âbidîn, Hâshiyah, 387.

${ }^{81}$ Shams al-Dîn al-Ṭarablisî, Mawâhib al-Jalîl li Sharh Mukhtạsar Khalìl, Vol. III (t.tp.: Dâr 'Âlam al-Kutub, 2003), 289.

82 Al-Ṭarablisî, Mawâbib, 289

83 Al-Ṭarablisî, Mawâbib, 289

${ }^{84}$ Muḥammad 'Arafah al-Dasûqî, Hâsshiyah al-Dasûqî 'alâ al-Sharh al-Kabîr, Vol. I (Beirut: Dâr al-Fikr, t.th.), 512.

85 Shihâb al-Dîn al-Qarafî, Al-Dakhîrah, Vol. XIII (Beirut: Dâr al-Gharbî, 1994), 342.

${ }^{86}$ Al-Sâwî, Balaghat al-Sâlik, Vol. I 443.

${ }^{87}$ Al-Kharshî, Sharh Mubtạsar Khalîl, Vol. II 237.

88 Al-'Abdarî, Al-Tâj wa Iklîl li Mukhtạsar Khalîl, Vol. II 387.

${ }^{89}$ Al-Ṭarablisî, Mawâhib al-Jalîl Li Sharh Mukbtạsar Khalîl, Vol. III 289.

${ }^{90}$ Al-Dasûqî, Hâshiyah al-Dasûqî 'alâ al-Sharh al-Kabîr, Vol. I 512.

${ }^{91}$ Al-Kharshî, Sharh Mubtạsar Khalîl, Vol. II 237.

92 Al-'Abdarî, Al-Tâj, 387.

${ }^{33}$ Al-Ṭarablisî, Mawâhib al-Jalîl Li Sharh Mukhtạsar Khalîl, Vol. III 289. 
bahkan Ibn al-'Arabî mengingkari pendapat yang disandarkan pada ulama' shâfi'îyah. Menurut Ibn al-'Arabî bahwa yang memperbolehkan berpedoman pada ilmu hisâb hanyalah Ibn Shurayj (Shâfîîyah) dan beberapa tâbi'în seperti Mụtraf bin 'Abdillâh. ${ }^{94}$ Imam al-Qarâfî menyampaikan ilmu hisâb dalam beberapa hal boleh dijadikan pedoman, seperti penentuan waktu shalat. Namun dalam penentuan ramadlan dan syawal hal ini tidak boleh. ${ }^{95}$ Menurut penulis, apa yang di sampaikan alQarâfî menunjukkan bahwa beliau mengakui tentang kepastian (qạt') hasil ilmu hisâb sebagaimana yang diungkap oleh beberapa ulama' shâfi'îyah. Namun demikian, menurut al-Ṭarablisî dan Ibn 'Alîsh bahwa sekalipun memang hasilnya pasti, namun 'illat wajibnya shalat dengan puasa ramadlan atau hari raya berbeda. Misalnya dalam hal shalat dzuhur, Allah menetapkan bahwa sebab wajibnya adalah zawal al-shams (tergelincirnya matahari), sedangkan sebab wajibnya puasa atau hari raya menurut ketetapan Allah bukanlah munculnya hilâl (bulan), tetapi sebab terlihatnya bilâl (ru'yat al-bilẩ), ${ }^{96}$ Sebagaimana hadîth:

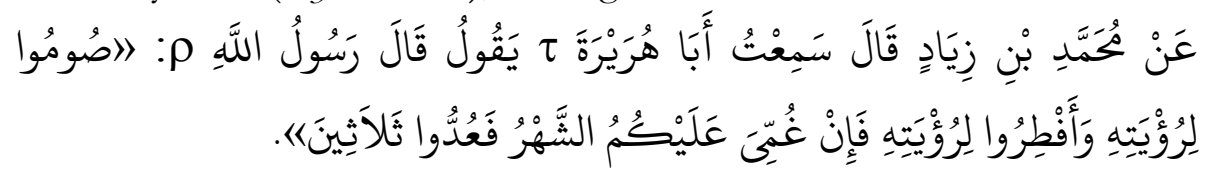

Artinya: "Dari Muhammad bin Ziyâd berkata, aku mendengar Abu harayrah berkata bahwa Rasulullab bersabda: Pusalah kalian karena melihat bilâl. Dan berhari rayalah kalian karena melihat hilâl. Jika hilâl tertutupi bagi kalian, maka genapkanlah tiga pulub" 97

Menurut mayoritas shâfi'îyah bahwa ilmu hisâb tidak dapat dijadikan pedoman dalam penentuan hari raya dan puasa, dan pendapat ini dinilai sebagai pendapat shâfi'îyah yang paling kuat dijadikan pedoman, sebagaimana diungkapkan Abû Bakar al-Dimyậtî selaku muta'akekbirin di kalangan shâfi'iyah.

Dalam fạth al-bârî karya Ibn Hajar al-Asqalânî dikatakan bahwa Ibn al'Arabî mengkritik pendapat dari Ibn Surayj yang menyatakan bahwa kalimat فَاقْدرُوْا لَ dalam hadîth itu ditujukan untuk orang-orang tertentu

\footnotetext{
94 Al-Ṭarablisî, Mawâhib, 289

${ }^{95}$ Al-Qarafî, Al-Dakhîrah, Vol. XIII 342.

${ }^{6}$ Al-Ṭarablisî, Mawâhib al-Jalîl li Sharh Mukhtạsar Khalîl, Vol. III 290; Muḥammad bin 'Alîsh, Fath al-'Alì al-Mâlik, Vol. I (t.tp.: Maktabah Shamelah, t.th.), 411-412.

${ }^{97}$ Al-Bukhârî, Al-Jâmi' al-Sabị̂, Vol. II 674; Muslim, al-Jâmi’ al-Sabị̂̂, Vol. III 124.

98 Abû Bakr al-Dimyậtî, Hâshiyah, 216.
} 
فأكملوا العدة dalam hadîth lain yang sejenis ditujukan untuk orang awam. Maka menurut Ibn al-'Arabi ketentuan Ibn Surayj tentang kewajiban Ramadlan (juga idul fitri) yang berbeda dengan melihat kondisinya adalah ketentuan yang jauh (sulit dicerna). ${ }^{99}$ Begitu juga Ibn Ṣalâh juga menyatakan bahwa mengetahui perhitungan rembulan adalah masalah yang sangat detail dan terperinci yang hanya diketahui oleh beberapa individu. Maka ketentuan seperti ini hanya bias diterapkan khusus bagi dirinya sendiri. ${ }^{100}$

Imam al-Nawâwî menyampaikan bahwa mayoritas ulama menyatakan jika bilâl sulit dilihat karena tertutupi awan maka harus disempurnakan menjadi 30 hari, bukan dengan cara melakukan bisâb ilmu falak (perhitungan kalender dengan ilmu astronomi) karena menurut Imam alNawawi, jika perintahnya harus melakukan hisâb ketika bilâl tertutup mendung, maka akan menyulitkan bagi umat sebab hanya orang tertentu yang mampu menguasai bisâb ilmu falak. ${ }^{101}$

Walaupun banyak kritik bermunculan terhadap metode ini bahkan oleh kalangan shâfi'îyah sendiri, namun al-Rawyânî berusaha untuk tidak mempertentangkan, dengan menyatakan Ibn Surayj tidak pernah mewajibkan untuk menggunakan ilmu astronomi, melainkan sebuah kebolehan. Pendapat inilah yang dipilih oleh al-Qaffâl dan Abû Tayyib. ${ }^{102}$

Pemberlakuan ilmu falak di daerah yang tidak mungkin dilakukan ru'yat al-hilâl seperti wilayah dekat kutub juga dibantah oleh Wahbah Zuhaylî. Bolehkan menggunakan perhitungan astronomi secara mutlak, bolehkah ru'yat al-hilâl dengan alat, dan bolehkah menerima kabar atau perhitungan astronomi orang non muslim dalam menentukan bulan ramadlan dan syawal. Menurut Wahbah Zuhaylî dinyatakan bahwa dalam kondisi yang demikian penentuan bulan Ramadlan dan Syawal tetap harus menggunakan ru'yat al-hilâl dengan bantuan ilmu astronomi sebagai media ru'yat al-hilâl karena harus tetap menjaga perintah hukum (khịtâb) dalam hadîth Rasul saw serta kebenaran ilmiah. ${ }^{103}$

Namun demikian faktanya, ilmu hisab ternyata sampai saat ini tetap dipelajari oleh banyak kalangan dari berbagai mazhab bahkan tetap dijadikan sebagai metode dalam memutuskan puasa dan hari raya,

\footnotetext{
${ }^{99}$ Ibn Ḥajar al-Asqalânî, Fath al-Bârî, Vol. IV (Beirut: Dâr al-Ma'rifah, t.th.), 123.

100 Ibn Hajar, Faț al-Bârî, 123.

101 Al-Nawâwî, Sharh Sabîh al-Muslim, Vol. VII, 186.

102 Al-Asqalânî, Fatḩ al-Bârî, Vol. IV 123.

103 Wahbah, al-Fiqh al-Islâmiy Wa Adillatubu, Vol. VII 122.
} 
bahkan muncul istilah ilmu hisab yang sifatnya taqrîb̂̂ (hasilnya mendekati kebenaran) dan yang sifatnya tahîq î (hasilnya lebih tepat) sebagaimana yang terjadi di Indonesia.

\section{Fiqh Mazhab Penguasa}

Fikih mazhab penguasa merupakan istilah baru dalam menyebut fikih hasil ijtihad khulafâ' al-rashidûn pasca wafatnya Rasulullah saw. Perlu diketahui bahwa pada masa khulafâ' al-rashidûn telah terjadi beberapa ijtihad atau pemikiran hukum yang dilakukan oleh para khalifah dan para sahabat Rasululullah saw, bahkan ketika Rasulullah masih hidup pun telah terjadi berbagai macam ijtihad para sahabat, hanya saja hasil ijtihad pada masa Rasulullah terkadang akan disikapi oleh wahyu (al-Qur'an atau hadîth) dan terkadang Rasulullah diam. Diamnya Rasulullah saw tersebut dinilai sebagai sunnah taqrîryah (sunnah dalam bentuk penetapan). ${ }^{104}$ Sedangkan pemikiran hukum Islam pasca wafatnya Rasulullah saw sangat banyak mengingat problematika yang terus berkembang hanya saja pemikiran hukum yang digali oleh khulafâ' al-râshidûn menjadi produk hukum yang berlaku sangat efektif mengingat bersumber dari pemerintah. ${ }^{105}$ Di antara pemikiran hukum khulafâ' al-râshidûn:

Pertama, pemikiran hukum khalîfah Abû Bakar tentang memerangi orang-orang yang tidak mau membayar zakat pasca Rasulullah saw wafat walaupun hal ini pada mulanya banyak ditentang oleh para sahabat yang lain seperti 'Umar bin Khațâb karena pemikiran khalîfah Abû Bakar ini secara lahir dinilai bertentangan dengan nạss (hadîth):

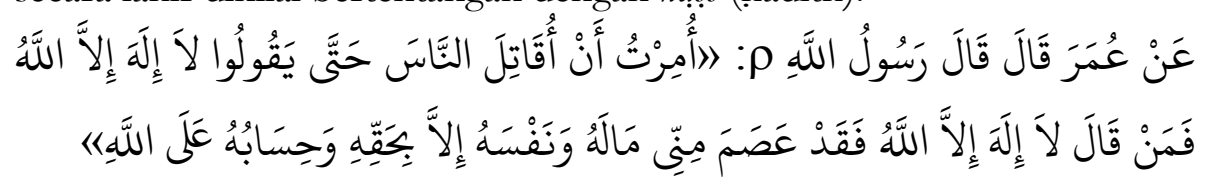

Artinya: "Dari Umar bin Khattâb berkata, Rasulullab saw bersabda: "Aku diperintah untuk memerangi manusia sampai mereka menyatakan tidak. ada tuhan selain Allah. Maka barang siapa yang telah mengucapkan maka hartanya dan juwanya benar-benar terjaga dariku. Adapun hisâbnya kelak urusannya dengan Allah swt." 106

Namun berdasarkan musyawarah khalîfah Abû Bakar dengan para pembesar sahabat, akhirnya para pembesar sahabat membenarkan apa yang dicetuskan oleh khalîfah Abû Bakar dan akhirnya dijadikan sebagai

\footnotetext{
104 Shobirin, Fiqh Madz̧hab Penguasa (Kudus: Brilian Media Utama, 2009), 3.

105 'Abd al-Raḥmân al-Suyụtî, Târîkh al-Khulafâ' (Mesir: Mạtba' al-Sa'âdah, 1952), 67-100. 106 al-Bukhârî, Al-Jâmi’ al-Sabị̂h, Vol. III 1077; Muslim, al-Jâmi’ al-Sabị̂̂, Vol. I 38.
} 
keputusan khalîfah yang ditindaklanjuti dengan mengutus tentara sebanyak sebelas peleton yang kesemuanya dipimpin oleh Khâlid bin alWalîd. ${ }^{107}$ Jika ditelaah, keputusan memerangi pembangkang zakat lebih memilih nasss lain (men-tarị̂h nasss lain) sebagai landasannya, yaitu ayat tentang kewajiban untuk shalat dan membayar zakat dalam QS. alBaqarah: 43;

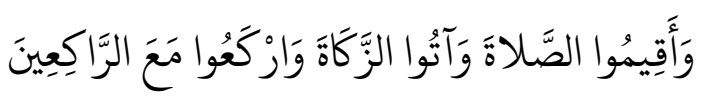

Artinya: "Dan dirikanlah shalat, tunaikanlah zakat dan ruku'lah beserta orangorang yang ruku'."

Kedua, pemikiran hukum 'Umar bin Khattâb tentang tidak memberikan zakat pada golongan mu'allafat qulububum walaupun ditentang beberapa sahabat lain karena bertentangan dengan nasss yang secara jelas menyebut bagian mu'allafat qulübubum, ${ }^{108}$ sebagaimana QS. al-Taubah: 60;

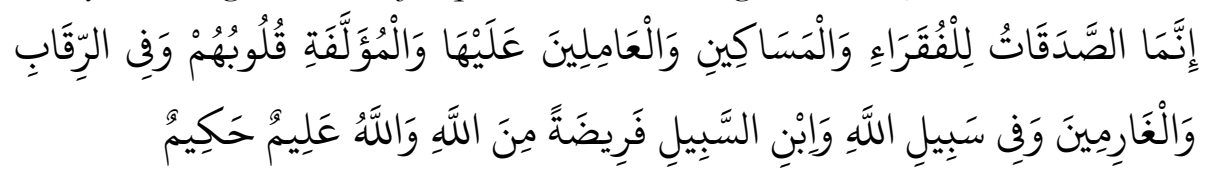

Artinya: "Sesunggubnya zakat-zakat itu, hanyalah untuk orang-orang fakir, orang-orang miskin, pengurus-pengurus zakat, Para mu'allaf yang dibujuk batinya, untuk. (memerdekakan) budak, orang-orang yang berbutang, untuk jalan Allah dan untuk mereka yuang sedang dalam perjalanan, sebagai suatu ketetapan yang diwajibkan Allab, dan Allah Maha mengetahui lagi Maha Bijaksana."

Sepertinya khalîfah 'Umar bin Khațtâb melihat ulang 'illat ditetapkannya mu'allafat qulûbubum sehingga beliau menggugurkannya. Sebagaimana ungkapan beliau ketika beberapa golongan mu'allaf protes dengan mendatangi khalîfah 'Umar bin Khattâb. Lalu beliau menjawab, "Ini memang dabulu diberikan oleh Rasulullah kepada kalian agar mendekatkan atau melunakkan hatimu (pada Islam). Sekarang Allah telah memuliakan Islam dan Islam tidak memerlukanmu lagi. Jika kamu tetap pada Islam (terserah) dan jika tidak. maka di antara kita adalah pedang". ${ }^{109}$

Jika ditelaah, selain menganggap 'illat telah tiada, keputusan khalîfah 'Umar bin Khattâb ini dilandasi oleh ḥadîth:

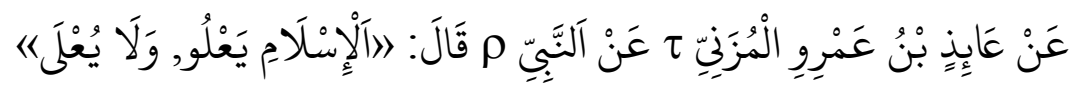

\footnotetext{
107 Shobirin, Fiqh Madz̧hab Penguasa, 173; Ibn Khaldûn, Târîkh Ibn Khaldûn, Vol. II (t.tp.: Maktabah Shamelah, t.th.), 74-75.

108 Shobirin, Fiqh Madzhab Penguasa, 180.

${ }^{109}$ Shobirin, Fiqh Madzhab Penguasa, 185.
} 
Artinya: "Dari 'Aidh bin 'Amr al-Muzanni, Rasulullah bersabda: Islam itu tinggi derajatnya dan tidak ditinggikan (dengan merendabkan Islam).",10

Ketiga, pemikiran hukum khalîfah 'Uthmân bin 'Affân tentang penangkapan unta-unta liar yang tidak dirawat dalam kandang oleh pemiliknya walaupun ditentang oleh beberapa sahabat karena dianggap bertentangan dengan hadîth Rasulullah, ${ }^{111}$ karena beliau sempat melarang untuk menangkap unta-unta berkeliaran:

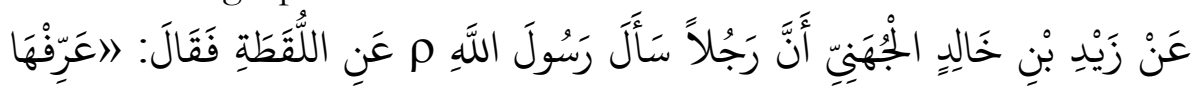

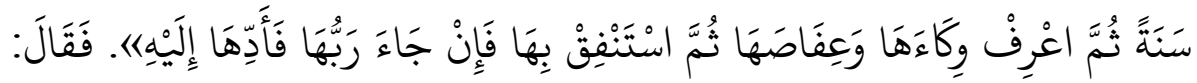

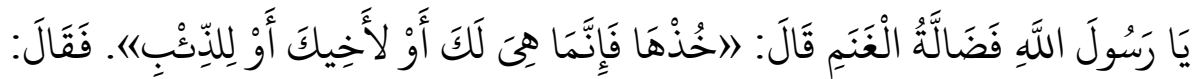

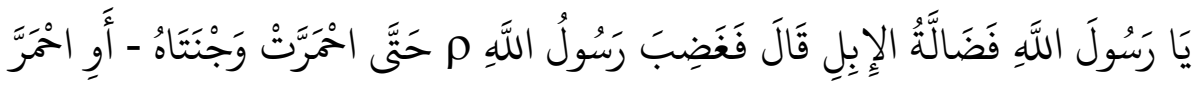

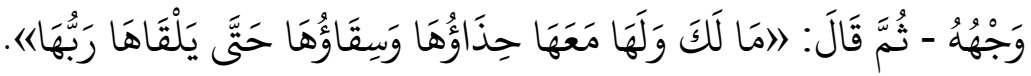

Artinya: Dari Zayd bin Khâlid al-Juhnî, bahwa ada laki-laki vertanta pada Rasulullah saw tentang harta temuan, Lalu Rasulullab bersabda, "umumkanlab selama satu tabun tentang ciri-cirinya dan sifatnya. Lalu nafkabkanlah (jika tidak ada pemiliknya). Jika pemiliknya dating maka berikanlah padanya". Lalu orang itu bertanya tentang temuan berupa kambing, Rasulullah saw menjawab, "Ambilla karena mungkin milikmu, atau milik saudaramu ata akan dimakan serigala". Lalu rasululah ditanya tentang temuan berupa unta, maka Rasulullah saw murka sampai wajahnya memerah dan menjawab, "Apa urusanmu dengan unta itu. Biarkanlah ia mencari minum sampai ditemukan oleh pemiliknya." 112

Jika ditelaah, sepertinya khalîfah 'Uthmân bin 'Affân melihat illat berupa maslabah ketika menetapkan penangkapan unta-unta liar lalu menjualnya serta jika pemiliknya mencarinya akan diberikan hasil penjualan tersebut. Illat pembiaran unta pada masa Rasulullah adalah kondisi aman karena tidak ada indikasi pencurian unta. Sementara pada masa khalîfah 'Uthmân bin 'Affân sepertinya 'illat itu sudah tidak ada, artinya kondisi sudah tidak aman karena adanya indikasi pencurian

110 'Alî bin 'Umar al-Dâruqụtnî, Sunan al-Dâruqụtnî, Vol. III (Beirut: Dâr al-Ma'rifah, 1966), 252.

111 Shobirin, Fiqh Madzhab Penguasa, 222.

112 al-Bukhârî, Al-Jâmi' al-Sabị̣̂, Vol. II 856; Muslim, Al-Jâmi’ al-Sabị̣̂, Vol. V 134. 
unta. ${ }^{113}$ Oleh sebab itu, pemilihan 'illatnya dirubah oleh khalîfah karena dianggap lebih maslabah. Kemudian dilakukan qiyas terhadap harta temuan selain unta dengan asal atau dasar qiyas berupa hadith di atas dalam redaksi yang awal.

Keempat, pemikiran hukum khalîfah 'Ali bin Abî Tâlib tentang hukuman peminum khamr (miras) berupa 80 kali cambukan. Berbeda dengan zina yang jumlah cambukan dijelaskan, namun jumlah cambukan peminum khamr tidak dijelaskan dalam Al-Qur'an. Keputusan ini juga banyak ditentang sahabat karena Rasulullah saw menghukum peminum khamr sebanyak 40 kali, ${ }^{114}$ sebagaimana hadîth:

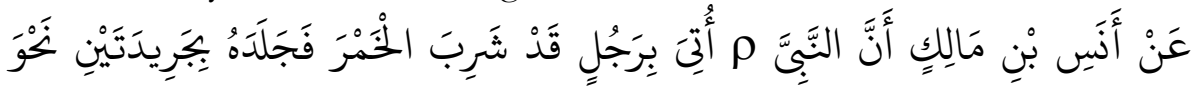
أََْبَعِينَ

Artinya: "Dari Anas bin Mâlik, bahwasannya ada laki-laki yang didatangkan pada Rasulullah saw karena terbukti minum khamr. Lalu Rasulullah mencambuknya sebanyak 40 kali cambukan.",15

Jika ditelaah, sebenarnya keputusan khalîfah 'Ali bin Abî Tâlib tidak bertentangan dengan keputusan Rasulullah saw karena 40 kali cambukan juga dilakukan oleh khalîfah 'Ali bin Abî Tâlib, hanya saja terdapat tambahan 40 kali dalam hal ini. Penambahan ini teramati lebih mengedepankan sadd al-dharìah. Artinya menutup pintu bahaya yang ditimbulkan pada saat itu karena peminum khamr masih merajalela sehingga dampaknya terhadap kejahatan lainnya sangat dikhawatirkan, sebab pada saat itu wilayah Islam tidak hanya di sekitar Hijaz. Hal ini bisa kita lihat pada ungkapan khalîfah 'Ali bin Abî Ṭ̂alib:

عن أبى عبد الرحمن السلمى عن على قال شرب نفر من أهل الشام الخمر وتأولوا الآية الكريمة فاستتشار فيهم فقلت أرى أن تستتيبهم فإن تابوا ضربتهم ثمانين

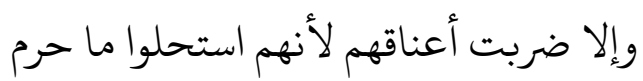

Artinya: "Dari Abûu 'Abdurrabmân al-Silmi, dari Ali berkata, "beberapa golongan di daerah Syiria banyak yang meminum khamer. Para pemimpin mereka berusaba untuk menerjamah ayat-yata khamer, lalu mereka bermusyawarah denganku. Maka aku berkata bahwa ajaklah

\footnotetext{
113 Shobirin, Fiqh Madzhab Penguasa, 222.

114 Shobirin, Fiqh Madzhab Penguasa, 224.

115 Muslim, Al-Jâmi' al-Sabîh, Vol. V 125.
} 
peminum khamer itu bertaubat, jika berkenan maka hukumlah dengan 80 kali, jika tidak man maka potonglab lehernya karena telah menghalalkan apa yang diharamkan Allah.",116

Teramati bahwa ijtihad yang dilakukan oleh khulafâ' al-râshidûn sebagaimana disebutkan beberapa contohnya di atas semuanya terlihat bertentangan secara lahir dengan nasss tetapi sejatinya tetap sejalan dengan shari'ah karena tetap didasarkan pada nașs lain. Model ijtihad khulafâ' alrâshidûn yang memunculkan fiqh mazhab penguasa ini teramati memiliki beberapa langkah: (a) ijtihad dilakukan oleh orang yang ahli secara bersama-sama (ijtihad jama'); (b) ijtihad terkait masalah fiqh yang ijtibâdiyab; (c) melihat ulang fiqh klasik terkait masalah ini; (d) membaca ulang sumber nasss berikut illat hukumnya yang dijadikan sebagai media ijtihad. Jika terjadi pertentangan, maka dilakukan tarjị̂ al-adillah atau aljam'u; (e) membaca ulang makna nạss melalui qiyâs atau qẫidat lughawîyah yang lain; (f) melihat kebutuhan maslabah karena adanya madârat yang timbul dalam masyarakat; (g) menetapkan hukum atau hasil ijtihad berdasarkan naṣs wahyu hasil tarị̂h, maslabah yang didukung oleh nạ̣s (maslabat mu'tabarah) atau atau maslabah yang tidak ditentang oleh nạss (maslahat mursalab); (h) mengedepankan sadd al-dharìah dalam hasil ijtihadnya; dan (i) Mengedepankan ketegasan untuk menjaga kewibawaan pemerintah dan kewibawaan hukum.

Diilhami dari model dan hasil pemikiran hukum kbulafâ' al-râshidûn yang kemudian dijadikan sebagai kebijakan Negara pada saat itu, maka tentunya negara dalam hal ini ûlî al-amr (pemerintahan) setelah masa khulafâ' al-râshidûn di manapun berada dapat menetapkan fikih atau ijtihad baru yang kemudian dapat dijadikan sebagai hukum yang harus ditaati oleh seluruh rakyatnya. Ijtihad semacam ini layak disebut sebagai fikih mazhab Negara, tentunya dengan metode ijtihad yang benar dan dilakukan oleh mujtahid yang memiliki kualitas keilmuan di bidang hukum Islam serta minimal mengikuti model atau metode ijtihad kbulafấ, al-rashidûn.

\section{Penetuan Hari Raya Model Fiqh Mazhab Penguasa}

Perbedaan pendapat di Indonesia tentang penentuan awal ramadlan dan idul fitri bermula dari metode penetapannya yang masing-masing Ormas Islam di Indonesia berbeda. Pada dasarnya masalah khilafiyah

116 Muhammad bin 'Alî al-Shawkâni, Nayl al-Aẉtâr, Vol. VII (t.tp.: Maktabah Shamelah, t.th.), 190. 
biasa terjadi dan wajar. Namun menjadi tidak wajar dan serius ketika produk ketetapan pemerintah yang seharusnya dipatuhi ternyata tidak dipatuhi. Kewibawaan pemerintah dan hukum menjadi hilang.

Content masalahnya berupa penentuan awal ramadlan dan hari raya yang sifatnya ijtihâdîyah sebagaimana pencarian arah qiblat dan waktu shalat. Sedangkan metode penentuan awal ramadlan dan hari raya dalam fiqh klasik sudah khilâf walaupun lebih banyak yang mendukung keberadaan metode ru'yat al-bilâl. Masing-masing pendapat memiliki argumentasi ilmiah sebagaimana telah diungkap di atas.

Pemerintah dalam menetapkan hukum yang ingin diakui kebenarannya dan dilaksanakan oleh masyarakat awam tentunya harus merujuk pada hukum yang mudah dicerna akal. Sebagaimana pendapat al-Shâtibî yang menyatakan bahwa mujtahid dalam menetapkan tuntutan akidah atau hukum 'amaliyah (fikih) tentunya harus merujuk pada hukum yang mudah dicerna akal atau mudah difahami. Jika hukum ditetapkan dan dilaksanakan secara sulit dan hanya dapat dilakukan oleh orangorang tertentu, maka hukum tersebut bukanlah hukum shara' yang sifatnya umum dan tidak berlaku bagi masyarakat awam. ${ }^{117}$ Al-Shâtibî juga menyatakan bahwa tidak ada tuntutan untuk menentukan bilâl dengan perhitungan ilmu astronomi sebab ilmu itu bukanlah ilmu yang dikuasai orang arab (saat turunnya wahyu), sebab detailnya ilmu itu dan sebab sulitnya menguasai ilmu itu. Oleh karenanya hanya cukup dengan melihat persangkaan kuat yang menduduki derajat keyakinan. Dan orang awam tidak ada dosa jika tidak menguasainya serta cukup untuk mengikuti mayoritas ulama'. ${ }^{118}$

Teramati bahwa secara logika ru'yat al-bilâl bi al-'ayn memang lebih bagus dilaksanakan daripada menggunakan hisâb dengan ilmu falak, sebab jumlah hari dalam bulan qamariyyah tidak pasti seperti bulan shamsiyyah. Bulan qamariyyah dalam satu bulan memiliki dua kemungkinan, yaitu 29 atau 30. Sementara bulan shamsiyyah memiliki jumlah hari yang pasti. Kondisi bulan qamariyyah yang berada dalam dua kemungkinan menurut fikih adalah kondisi keraguan dan ketidakjelasan. Dalam kaidah fikih, kondisi seperti ini harus dikembalikan kepada al-yaqîn (hukum yang kebenarannya didasarkan pada sebuah kepastian, bukan prasangka dan keraguan) dengan:

Pertama, Mengembalikan kepada kenyataan yang jelas (al-dâhir). Memprioritaskan ru'yat al-bilâl bil-'ayn dari pada hisâab ilmu falak (ru'yat al-

117 Ibrahîm bin Mûsâ al-Shâtịî, Al-Muwafaqât, Vol. II (t.tp.: Dâr Ibn 'Affân, 1997), 142. 118 Al-Shâtibî, Al-Muwafaqât, 142-143. 
bilâl bi-ilm) adalah bentuk dari mengembalikan pada kenyataan yang jelas (al-dâhir). Mensyaratkan adanya persaksian dalam menetapkan hari raya adalah juga bentuk dari mengembalikan pada kenyataan yang jelas (aldâhir).

Kedua, mengembalikan kepada hukum asal (al-asl) sesuai dengan kaidah fikih:

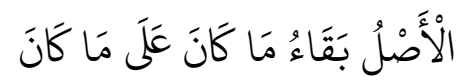

Artinya: "Hukum yang asal adalah tetapnya perkara yang sebelumnya telah tetap "119

Menghadapi masalah fiqh yang ijtihâdîyah-khilaffỹah semacam ini tidak ada salahnya bahkan harus dikembalikan pada pemerintah. Dan masalah kbilafizyah yang sudah diputuskan oleh pemerintah (hakim) menjadi selesai, sebagaimana kaidah:

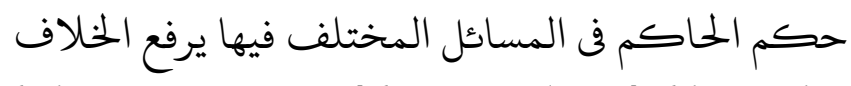

Artinya: "Ketentuan hakim tentang masalah yang diperselisibkan akan menghilangkan perselisiban itu,"120

Kaidah ini selain memberikan arahan bahwa perbedaan metode penentuan dan waktu hari raya menjadi selesai jika telah ditetapkan pemerintah (hakim), juga mengimpilkasikan bahwa hukum yang bertentangan dengan ketetapan pemerintah menjadi tidak diakui sama sekali dalam Islam.

Fiqh klasik juga telah menerangkan adanya campur tangan pemerintah dalam penentuan puasa dan hari raya. Semua mazhab menyatakan penentuan hari raya harus dipersaksikan di depan hakim. Di tunjang dengan nạss hadith bahwa Rasulullah saw yang saat itu kapasitasnya selaku pimpinan Negara Madinah telah mencontohkan cara menetapkan awal puasa dan hari raya. Sebagaimana riwayat:

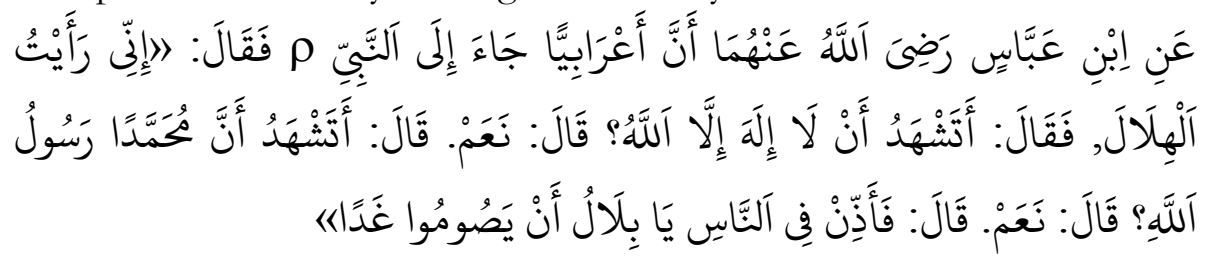

Artinya: "Dari Ibn Abbas bahwa A'robi dating kepada Nabi dan berkata, "Aku melibat bilâl". Lalu Rasul bersabda, "Apakah kau bersaksi

${ }^{119}$ Ibn Nujaym, Al-Ashbah, 57.

120 Al-Zarkashî, Al-Manthûr fî al-Qawâid, Vol. II (Kuawait: Wizârat al-Shu'ûn, t.th.), 29. 
bahwa tiada Tuban selain Allab?". Ia menjawab, "ya”. Rasul bersabda, "Apakah kau bersaksi bahwa Mubammad utusan Allab?". Ia menjawab, "iya". Lalu Rasulullah bersabda, "Kumandangkanlah adzan wahai bilal agar masyarakat besok puasa". ${ }^{121}$

Apa yang dilakukan oleh Rasulullah saw merupakan petunjuk bahwa pemerintah memiliki hak untuk menetapkan awal puasa dan hari raya sebab saat itu Rasulullah juga berkapasitas sebagai pimpinan Negara Madinah. Sebagian ulama' dan Ormas Islam di Indonesia mungkin hanya melihat bahwa apa yang dicontohkan oleh Rasulullah saw dalam hadîth itu merupakan salah satu metode bukan metode pasti penetapan awal Ramadlan dan hari raya. Tetapi seharusnya melihat hadîth harus secara komperehnsif, yaitu perlu dilihat juga urutan teknis yang ada pada hadîth itu. Metode yang terpilih pada hadîth itu adalah metode rukyah (ru'yat albilal bi al-'ayn). Dan selanjutnya hasil dari pelaksanaan metode itu tetap disampaikan kepada Rasulullah saw, tidak langsung diumumkan oleh pelaksana metode tersebut. Hal ini menunjukkan bahwa penentuan awal ramadlan dan hari raya harus melalui pemerintah.

Penentuan puasa dan hari raya adalah wilayah publik bukan privat karena berpengaruh terhadap aktifitas dan tugas di masyarakat di Indonesia, tidak dapat dilakukan oleh masing-masing individu serta rentan menimbulkan gesekan sesama umat muslim di wilayah masyarakat awam. Penentuan puasa dan hari raya bias dikategorikan urusan privat, tetapi masalah ini berdampak pada mafsadah sosial yang luas. Khalîfah Abû Bakar al-Siddîq pernah menyelesaikan masalah yang sejenis, yaitu dengan membuat kebijakan bahwa orang yang murtad dan orang yang tidak mau membayar zakat harus diperangi padahal urusan masuk atau keluar dari Islam adalah urusan privat. ${ }^{122}$ Keputusan khalifah Abû Bakar ini memang tidak luput dari pertentangan pemikiran, bahkan Umar bin Khațtâb awalnya sangat tegas menolak. Berdasarkan asas musyawarah, dalam musyawarah ini muncul dua opsi. Pertama, membiarkan para pembangkang zakat dengan harapan dapat membantu umat muslim dalam menghadapi Romawi dan Persia. Kedua, memerangi mereka berarti juga menambah musuh umat muslim. ${ }^{123}$ Musyawarah akhirnya

${ }^{121}$ Ibn Hajar al-Asqalânî, Bulûgh al-Marâm (t.tp.: Maktabah Shamelah, t.th.), 241.

122 Philip K. Hitti, History Of The Arabs (Jakarta: Serambi Ilmu Semesta, 2010), 176.

${ }^{123}$ Jaih Mubarak, Sejarah Peradaban Islam (Bandung: Pustaka Islamika, 2008), 93. 
memutuskan opsi yang kedua sesuai dengan pendapatnya Abu Bakar. ${ }^{124}$ Keputusan ini karena para pembesar sahabat sadar tentang pentingnya menanggulangi dampak mafsadah sosial serta adanya kesadaran bahwa Abû Bakar adalah pempimpin Negara pada saat itu yang memiliki otoritas harus dipatuhi. Sebagaimana penerimaan Umar bin Khațtâb terhadap kebijakan khalifah Abû Bakar:

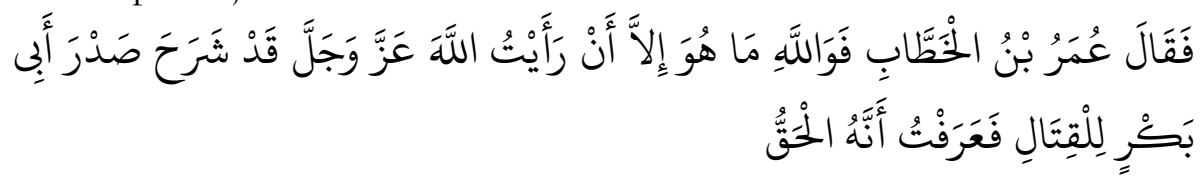

Artinya: Umar berkata: "Demi Allah, aku tidak ragu-ragu lagi. Au melihat bahwa Allah telah membukakan pintu hati Abu Bakar memerangi orang yang tidak mau membayar zakat, aku yakin bahwa tindakannya itu benar". 125

Dengan demikian dapat dinyatakan bahwa pemerintah memiliki otoritas untuk menentukan puasa dan hari raya. Otoritas pemerintah untuk menentukan puasa dan hari raya tersebut harus disertai dengan adanya otoritas pemerintah untuk ditaati. Artinya, keputusan yang ditetapkan oleh pemerintah bersifat mengikat pada semua muslim di wilayah Indonesia. Pemerintah Indonesia adalah pemerintah yang sah menurut hukum Islam yang oleh NU diistilahkan dengan walî al-'amr aldarûrî bi al-shawkah. Maka tidak ada alasan apapun untuk tidak mematuhi pemerintah. Otoritas pemerintah dalam Islam disetarakan dengan Allah dan Rasul sebagaimana telah dilegitimasi dalam QS. al-Nisa': 59;

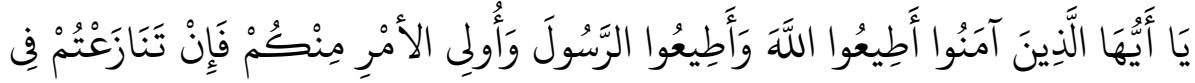

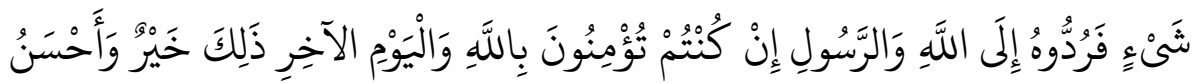
تَأْوِيلا

Artinya: "Hai orang-orang yang beriman, taatilah Allab dan taatilah Rasul (Nya), dan ulil amri di antara kamu. kemudian jika kamu berlainan Pendapat tentang sesuatu, Maka kembalikanlah ia kepada Allab (Al Quran) dan Rasul (sunnabnya), jika kamu benar-benar beriman kepada

124 Shobirin, Fiqh, 171; Sulaiman 'Abdullâh, Sumber Hukum Islam Permasalahan dan Fleksibilitasnya (Jakarta: Sinar Grafika, 1995), 167; Amir Syarifuddin, Ushul Fiqh, Vol. 2 (Jakarta: Logos Wacana Ilmu, 2008), 402.

125 Al-Bukhârî, Al-Jâmi' al-Sabị̂h, Vol. II 507; Muslim, Al-Jâmi' al-Sabị̂̂, Vol. I 38; Abû Dâud, Sunan Abî Dâud, Vol. II 01. 
Allah dan hari kemudian. yang demikian itu lebih utama (bagimu) dan lebih baik akibatnya."

Menurut al-Sha'rawi, pengulangan kata taatilah (أَطِيُوا) pada kalimat Allah dan Rasul sementara tidak ada pengulangan kata taatilah pada ulil amri menunjukkan makna bahwa taat kepada ulil amri memiliki subtansi mentaati Allah dan Rasulnya. ${ }^{126}$ Dengan kata lain, mentaati ulil amri adalah implementasi dari mentaati Allah dan Rasulnya. Tentunya dalam koridor ulil amri yang tidak memerintahkan maksiat. Maka tidak ada alasan untuk tidak mentaati pemerintah Indonesia. Terlebih masalah penentuan awal ramadlan dan hari raya.

Mengingat dalam penentuan hari raya di Indonesia erat kaitannya dengan banyak orang dan ormas, maka seyogyanya dalam menetapkannya pemerintah menggunakan model fiqh mazhab penguasa, yaitu dengan ijtihad bersama sebagaimana model khalifah Abû Bakar. Dalam arti menyepakati metode bersama dan benar-benar mempertimbangkan maslahah secara luas.

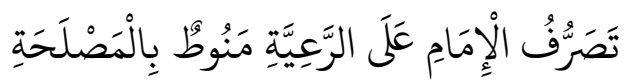

Artinya: "Tasarruf pemerintah (pemimpin) terhadap rakyat harus mengikuti maslahab" 127

\section{Kesimpulan}

Hasil dari pembahasan ini, dapat disimpulkan bahwa perspektif fiqh mazhab penguasa (1) pemerintah Indonesia memiliki otoritas penuh dalam menetapkan waktu dan metode penentuan hari raya dengan model ijtihad kolektif, dalam arti memilih metode penentuan hari raya dan waktu hari raya bersama perwakilan ormas. Dan (2) ketetapan pemerintah melalui ijtihad kolektif tentang hari raya harus ditaati dan memiliki kekuatan mengikat terhadap muslim di wilayah Indonesia.

\footnotetext{
126 Al-Sha'râwî, Tafsir al-Sha'râwî, Vol. I (t.tp.: Maktabah Shamelah, t.th.), 2345.

${ }^{127}$ Ibn Nujaym, Al-Ashbah, 123.
} 


\section{Daftar Pustaka}

'Abdarî (al), Muhammad bin Yûsûf. al-Tâj wa Iklîl li Mukhtạsar Khalîl. Beirut: Dâr al-Fikr, t.th.

'Âbidîn, Ibn. Hâashiyah Radd al-Mukbtâr. Beirut: Dâr al-Fikr, 2000.

'Alîsh, Muhammad bin. Faț al-'Alî al-Mâlik. t.tp.: Maktabah Shamelah, t.th.

'Ammâr, Abû al-Barakât Husayn bin. Marâqî al-Fallâh. t.tp.: Maktabah Shamelah, t.th.

'Ibâdî (al), Abû Bakar al-Haddâdî. Al-Jawharat al-Munîrah. t.tp.: Maktabah Shamelah, t.th.

Abdullah, Sulaiman. Sumber Hukum Islam Permasalahan dan Fleksibilitasnya. Jakarta: Sinar Grafika, 1995.

al-Qarafî (al), Shihâb al-Dîn. Al-Dakhîrah. Beirut: Dâr al-Gharbî, 1994.

Asqalânî (al), Ibn Hajar. Bulîgh al-Marâm. t.tp.: Maktabah Shamelah, t.th. . Faț al-Bârî. Beirut: Dâr al-Ma'rifah, t.th.

Bukhârî (al), Muḥammad bin Ismâ'il. Jâmi' al-Ṣahîh li al-Bukhâr̂̂. Beirut: Dar Ibn Kathîr, 1987.

Dardîr (al), Abû al-Barakât. Al-Sharh al-Kabîr li al-Dardîr. t.tp.: Maktabah Shamelah, t.th.

Dâruqụtnî (al), Alî bin 'Umar. Sunan al-Dâruqụtnî. Beirut: Dâr al-Ma'rifah, 1966.

Dimyậtî (al), Abû Bakar. Hâshiyah I'ânat al-Tâlibîn. Beirut: Dâr al-Fikr, t.th.

Haqq (al), Muhammad Shams. 'Awn al-Ma'bûd. Beirut: Dar al-Kutub al'Ilmiyah, t.th.

Hasil Muktamar Tarjih Muhammadiyah XXVI di Padang Tahun 2003

Haskafî (al), Alâ’ al-Dîn. Durr al-Mukhtâr. Beirut: Dâr al-Fikr, 2000.

Hitti, Philip K. History Of The Arabs. Jakarta: Serambi Ilmu Semesta, 2010.

Hujjâji (al), Muslim bin, Jâmi’ al-Ṣabîh li al-Muslim. Beirut: Dar al-Jayl, t.th.

Jazirî (al), 'Abd al-Rạ̣mân. Al-Fiqh 'alâ Madhâbib al-Arba'ah. t.tp.: Maktabah Shamelah, t.th.

Kharshî (al), Muhammad. Sharh Mụtạsar Khalîl. Beirut: Dâr al-Fikr, t.th.

Malîbârî (al), Zayn al-Dîn. Faț al-Mu'în. Beirut: Dâr al-Fikr, t.th.

Mâwardî (al). Al-Iqnâ' li al-Mâwardî. t.tp.: Maktabah Shamelah, t.th. . Al-Hânî al-Kabirr. Beirut: Dâr al-Fikr, t.th.

Mubarak, Jaih. Sejarah Peradaban Islam. Bandung: Pustaka Islamika, 2008.

101 Dliya'ul Chaq - Problematika Penentuan Hari Raya Perspektif Figh Madhhab Penguasa 
Mụsilî (al), Ibn Mawdûd. Al-Ikhtiyâr li Ta'lâl al-Mukhtâr. t.tp.: Maktabah Shamelah, t.th.

Nawâwî (al), Yahya bin Sharaf. Sharh Sabîţ al-Muslim. Beirut: Dar Ihyâ' alTurâth, t.th.

Nujaym, Zayn al-Dîn Ibn. Al-Ashbah wa al-Naz̧âiir. Beirut: Dâr al-Kutub al-'Ilmîyah, 1980.

Dâr al-Ma'rifah, t.th Al-Bậr al-Râiq Shaṛh Kan₹u al-Daqẩiq. Beirut:

Qurtubî (al), Yûsûf bin 'Abdillâh al-Namrî. al-Kâfî fi al-Figh Abli alMadînah al-Mâlikî. Riyad: Maktabah al-Riyâd al-Hadîthah, 1980.

Sarakhsî (al), Shams al-Dîn. Al-Mabsụ̂t li al-Sarakhsî. Beirut: Dâr al-Fikr, 2000.

Ṣ̂wî (al), Aḥmad bin Muhammad. Balaghat al-Sâlik. Beirut: Dâr al-Kutub, 1995.

t.tp.: Maktabah Shamelah, t.th.

Hâshiyah al-Sânî 'ala Sharh al-Saghîr.

Sha'râwî (al). Tafsir al-Sha'râwî. t.tp.: Maktabah Shamelah, t.th.

Shâfi'î (al), Muhammad bin Idrîs. Al-Umm. Beirut: Dâr al-Ma'rifah, t.th.

Shâtibî (al), Ibrahîm bin Mûsâ. Al-Muwafaqât. t.tp.: Dâr Ibn 'Affân, 1997.

Shawkâni (al), Muḥammad bin Alî. Nayl al-Aẉtâr. t.tp.: Maktabah Shamelah, t.th.

Shîrâzî (al), Ibrâhîm bin 'Alî. Al-Tanbîh. Beirut: 'Alam al-Kutub, t.th.

Shobirin. Fiqh Madz̧ hab Penguasa. Kudus: Brilian Media Utama, 2009.

Subkî (al), Tâj al-Dîn. Al-Ashbah wa al-Nazââir. Beirut: Dâr al-Kutub al'Tlmîyah, 1991.

Sulaiman, Abû Dâud. Sunan Abî Dâud. Beirut: Dar al-Kitab al-Arabi, t.th. Suyụ̂tî (al), 'Abd al-Rahmân. Al-Ashbah wa al-Nazẩìr. Beirut: Dâr alKutub al-'Ilmîyah, 1981.

1952. Târîkh al-Khulafâ’. Mesir: Mạtba’ al-Sa'âdah,

Syarifuddin, Amir. Ushul Figh. Vol 2. Jakarta: Logos Wacana Ilmu, 2008. Tarablisî (al), Shams al-Dîn. Mawâhib al-Jalîl li Sharh Mukbtasar Khalîl. t.tp.: Dâr 'Âlam al-Kutub, 2003.

Zarkashî (al). Al-Manthûr fì al-Qawâid. Kuawait: Wizârat al-Shu'ûn, t.th.

Zuhaylî, Wahbah. Al-Fiqh al-Islâmiy wa Adillatubu. Beirut: Dar al-Fikr, 2000. 